\title{
Production of intervarietal substitution lines with improved interspecific crossability in the wheat cv Courtot
}

\author{
G Gay, M Bernard* \\ INRA, Station d'Amélioration des Plantes, Domaine de Crouelle, F63039 Clermont-Ferrand Cedex 2, France
}

(Received 14 May 1993; accepted 8 October 1993)

\begin{abstract}
Summary - In order to involve the semi-dwarf wheat, cultivar Courtot in the development of primary triticale, we have attempted to improve its crossability with rye. The Courtot chromosomes 5A, 5B, 5D were replaced by their counterparts from the highly crossable Japanese cultivars Norin 29 and Fukuhokomugi, using the monosomic back-crossing technique. It was confirmed that the most potent compatibility factor was on the chromosome $5 \mathrm{~B}\left(\mathrm{kr}_{1}\right)$; this allele was sufficient to achieve a seed set of about $50 \%$, variable with environmental factors. Conversely, the effect of the 2 other chromosomes, whatever the donor parent, was hardly detectable: if they have the crossability alleles, these have a low level of expression, being inhibited by the $\mathrm{Kr}_{1}$ allele. Recovering the Courtot genetic background during the subsequent back-cross generations did not alter the degree of crossability estimated in $\mathrm{BC}_{1}$.
\end{abstract}

wheat / rye / triticale / crossability genes / substitution lines

Résumé - Production de lignées de substitution intervariétale dans le cultivar de blé Courtot et amélioration de son aptitude au croisement interspécifique. Dans le but d'utiliser le cultivar de blé demi-nain Courtot dans les programmes de création de triticales primaires, on a cherché à améliorer sa capacité de nouaison en croisement avec le seigle. Pour cela, on a remplacé ses chromosomes 5A, 5B et $5 D$ par ceux de 2 variétés japonaises hautement compatibles avec le seigle, Norin 29 et Fukuhokomugi, en utilisant les techniques du rétrocroisement sur des plantes monosomiques du parent récurrent. "I se confirme que l'allèle de compatibilité le plus puissant est bien sur le chromosome 5B (kr1): il permet l'obtention d'un taux de nouaison de l'ordre de $50 \%$, variable selon les conditions environnementales. L'effet des 2 autres chromosomes, quel que soit le parent de départ, n'est guère perceptible: s'ils portent des allèles de compatibilité, ceux-ci sont peu puissants et inhibés par l'allèle Kr. La récupération d'un fonds génétique "Courtot" au fur et à mesure du nombre de rétrocroisements ne modifie pas le niveau de compatibilité évalué en $B C_{1}$.

blé tendre/seigle/triticale/compatibilité au croisement interspécifique/lignées de substitution

\section{INTRODUCTION}

For more than a century (Rimpau, 1891), breeders have sought to combine the hardiness of rye (Secale cereale $\mathrm{L}$ ) with the productivity of common wheat (Triticum aestivum $L$ Thell ssp vulgare Mac Key). Wheat-rye hybrids are generally difficult to obtain and con- sequently the resulting number of hybrid combinations is limited. It is therefore necessary to develop methods aimed at enlarging the genetic variability of triticale ( $x$ Triticosecale Wittmack). The discovery of genetic factors which control the crossability of the species concerned (Backhouse, 1916) as well as that of the diploidizing role of colchicine have been decisive steps for the creation of this new spe-

\footnotetext{
* Correspondence and reprints.
} 
cies. In wheat, Lein (1943) showed the effects of the alleles $\mathrm{Kr}_{1}$ and $\mathrm{Kr}_{2}$ as crossability inhibitors. He proposed the following relationships between genotypes and phenotypes for wheat used as a female:

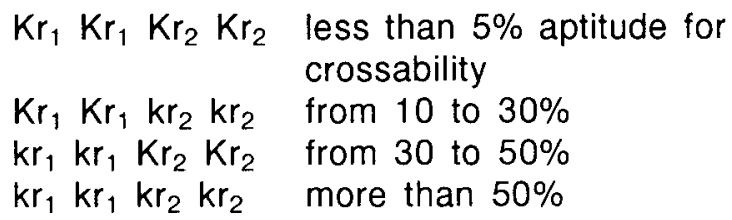

Riley and Chapman (1967) have located the loci of the genes on the homoeologous chromosomes of group 5: $\mathrm{Kr}_{1}$ on the long arm of chromosome $5 \mathrm{~B}$ and $\mathrm{Kr}_{2}$ on the long arm of chromosome $5 \mathrm{~A} . \mathrm{Kr}_{1}$ and $\mathrm{Kr}_{2}$ were mapped by Sitch et al (1985); $\mathrm{Kr}_{1}$ is at $44.8 \pm 3.3 \mathrm{cen}$ timorgans from the centromere on the $5 \mathrm{~B}$ and $\mathrm{Kr}_{2}$ is in a similar position on chromosome $5 \mathrm{~A}$. These results confirm that $\mathrm{Kr}_{1}$ and $\mathrm{Kr}_{2}$ are located at homoeologous loci. Another allele, $\mathrm{Kr}_{3}$, has been located on chromosome $5 \mathrm{D}$ by Krolow (1970).

Other factors of minor importance are involved in obtaining hybrid embryos between wheat and rye. Firstly, the $D$ genome, especially chromosome $1 \mathrm{D}$, is important in the formation of viable hybrid seed (Pienaar and Marais, 1976, 1986; Marais and Van Der Westhuizen, 1987, Marais, 1988). Secondly, the genotype of the rye parent also plays a role (Florell, 1931; Tozu, 1950; Kaltsikes, 1974; Marais and Pienaar, 1977; Taira et al, 1978; Scoles, 1983). Tanner and Falk (1981) demonstrated that some inbred rye lines partially circumvent one or even both inhibitor alleles present in wheat.

The $\mathrm{Kr}_{1}$ and $\mathrm{Kr}_{2}$ genetic system is also decisive in the crossability of common wheat with bulbous barley (Hordeum bulbosum L) used to produce common wheat haploids (Falk and Kasha, 1981; Fedak and Jui, 1982), but is not involved in the intergeneric crosses between bread wheat and maize (Zea mays L) (Laurie and Bennett, 1987, 1988; Inagaki and Tahir, 1990), which had made this latter method useful to obtain haploids with any common wheat genotype used to date.

The recessive alleles of the genes $\left(\mathrm{kr}_{1}, \mathrm{kr}_{2}\right)$ are present in some wheat genotypes originating from China, Japan, Eastern Siberia, and Iran (Zeven, 1987) whereas European bread wheat varieties have the dominant alleles $\mathrm{Kr}_{1}$ and $\mathrm{Kr}_{2}$, with a few exceptions, such as $\mathrm{cV}$ Roazon, which is derived from an in- terspecific cross (Stefanowska and Cauderon, 1983).

For this reason, we are developing wheat genotypes with the recessive alleles $\mathrm{kr}_{1}, \mathrm{kr}_{2}$, $\mathrm{kr}_{3}$, well adapted to local agronomic conditions, either by conventional pedigree breeding or by chromosome substitution. The latter case involves replacing chromosomes $5 \mathrm{~A}, 5 \mathrm{~B}$, 5D from a non-crossable, well-adapted genotype by the corresponding chromosomes from highly crossable genotypes.

Creating such substituted lines in a known wheat background would also reduce empiricism in obtaining primary triticales. The best genetic wheat $x$ rye combinations for characters such as ear fertility, chromosome stability, agronomic traits (size, lodging and disease resistance) and technological factors (shrivelling, $\alpha$-amylase activity) could then be selected from amphiploid populations developed in this way. The substitution lines would thus be used as a genetic basis for screening rye genotypes.

\section{MATERIALS AND METHODS}

Two Japanese wheat varieties, Norin 29 and Fukuhokomugi, known for their high crossability with rye, were chosen as donors of group 5 chromosomes.

Monosomic lines of cv Courtot, developed by INRA laboratories in the 1970s (Denis et al, 1982) were used as recipient material. Courtot was the first semi-dwarf wheat variety released in France (1974). It has the dwarfing genes $\mathrm{Rht}_{1}, \mathrm{Rht}_{2}$ of Norin 10 and is highly resistant to lodging. It is of semi-winter type and has good baking quality. It is, however, susceptible to numerous fungal diseases.

The method employed for creating substitution lines was described by Unrau et al (1956) and uses Courtot monosomics as female parent and monosomic individuals originating from back-crossing onto Courtot as the male parent (fig 1). Throughout the back-crosses, the substituted chromosome was maintained in the monosomic condition, and therefore could not be subject to recombination. The back-cross process was continued up to $\mathrm{BC}_{4}$ for chromosomes $5 \mathrm{~A}$ and $5 \mathrm{~B}$, and only up to $\mathrm{BC}_{1}$ for chromosome $5 \mathrm{D}$. After 4 backcrosses, monosomic plants were selfed, and the plants with $2 n=42$ were selected in the progeny. Chromosome number was checked at each generation by squashing, using the Feulgen staining technique. The meiotic behaviour of each plant 


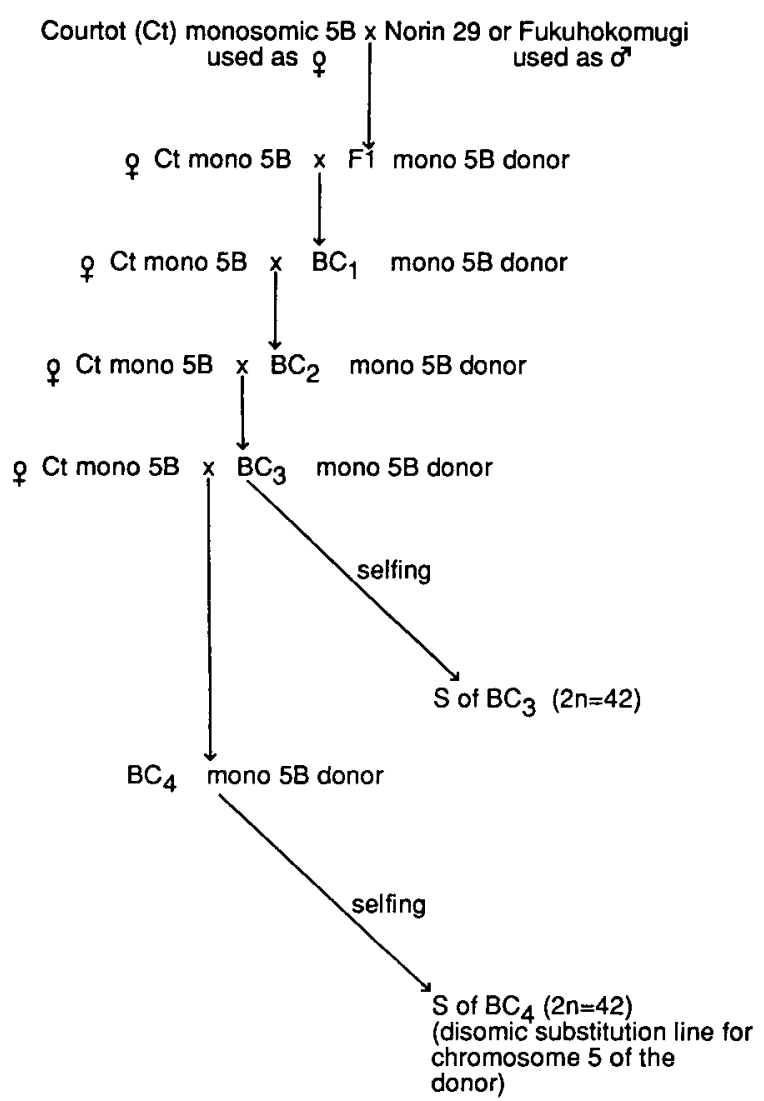

Fig 1. Construction of genotypes (as exemplified for chromosome 5B).

was observed on 25 pollen-mother cells stained with aceto-carmin (Cauderon and Gay, 1992).

All the parent genotypes, except Courtot monosomic 5A, were checked for their crossability with rye. At each back-cross generation, the substituted monosomic plants were crossed with rye to check for the presence of crossability genes and to ensure that no change in univalent had occurred.
We used the Beaulieu synthetic variety as the rye tester as it consistently provided abundant pollen. The monosomic wheat plants were grown in soil, either in a tunnel $\left(F_{1}, B C_{1}, B C_{2}\right)$ or in a greenhouse $\left(\mathrm{BC}_{3}, \mathrm{BC}_{4}\right.$, and progenies issued from $\mathrm{BC}_{3}$ and $\mathrm{BC}_{4}$ ).

\section{RESULTS}

The results obtained varied considerably due to environmental factors. Nevertheless, interspecific crossability of the parental genotypes, Norin 29, Fukuhokomugi and Courtot, is very contrasted (table 1): Norin 29 and Fukuhokomugi showed a very high seed set rate (95 and $86 \%$ ), much higher than Courtot $(7 \%)$. Of the Courtot monosomics, only monosomic 5B showed a relatively high seed set (18\%) (table I). The 22 grains obtained from this cross were put to germinate. Nine gave viable plantlets, 7 with 27 chromosomes and 2 with 28 chromosomes.

The pollination tests with rye carried out on monosomic F1s showed a high seed set only when the monosomic 5B was used as the parent. This rate was very low or zero with monosomics $5 \mathrm{~A}$ or $5 \mathrm{D}$ (table 1 ).

The crossability tests on $\mathrm{BC}_{1}, \mathrm{BC}_{2}, \mathrm{BC}_{3}$, $\mathrm{BC}_{4}$ plants showed seed setting ranging from 30 to $60 \%$ when the chromosomes $5 \mathrm{~B}$ from the 2 Japanese wheat varieties were involved, whereas it was zero or almost zero with chromosomes 5D and 5A (table II). The seed set of crosses on plants from $\mathrm{BC}_{3}$ and $\mathrm{BC}_{4}$ progenies with 42 chromosomes, disomic for chromosomes $5 \mathrm{~B}$ of Norin 29 and

Table I. Crossability level with rye of the parents, the Courtot monosomic 5B, 5D (5A not tested) and the monosomic F1 progenies.

\begin{tabular}{|c|c|c|c|c|c|c|c|c|c|}
\hline \multirow{3}{*}{$\begin{array}{l}\text { Identity of the genotypes } \\
\text { Courtot (Ct) }\end{array}$} & \multicolumn{6}{|c|}{ Presumed allelic composition } & \multirow{3}{*}{$\begin{array}{c}\begin{array}{c}\text { No of grains/ } \\
\text { No of flowers } \\
\text { pollinated }\end{array} \\
7 / 100\end{array}$} & \multirow{2}{*}{\multicolumn{2}{|c|}{$\begin{array}{c}\text { Estimate of } \\
\text { the seed set } \\
\text { and confidence } \\
\text { interval }\end{array}$}} \\
\hline & \multirow{2}{*}{$\begin{array}{c}K r_{1} \\
++\end{array}$} & \multirow{3}{*}{$\begin{array}{r}k r_{1} \\
++\end{array}$} & \multirow{2}{*}{$\begin{array}{l}K r_{2} \\
++\end{array}$} & \multirow{2}{*}{$k r_{2}$} & \multirow{2}{*}{$\begin{array}{r}K r_{3} \\
++\end{array}$} & \multirow[t]{2}{*}{$k r_{3}$} & & & \\
\hline & & & & & & & & 0.07 & \pm 0.05 \\
\hline Norin $29(\mathrm{~N} 29)$ & & & & ++ & & ++ & $57 / 60$ & 0.95 & \pm 0.06 \\
\hline Fukuhokomugi (Fuk) & & ++ & & ++ & & ++ & $52 / 60$ & 0.86 & \pm 0.09 \\
\hline Ct mono 5B & + & & ++ & & ++ & & $22 / 120$ & 0.18 & \pm 0.07 \\
\hline Ct mono 5D & ++ & & ++ & & + & & $0 / 100$ & 0.00 & \pm 0.04 \\
\hline F1 $($ Ct mono $5 \mathrm{~A} \times \mathrm{N} 29) \times$ rye & + & + & & + & + & + & $6 / 200$ & 0.03 & \pm 0.02 \\
\hline F1 (Ct mono $5 \mathrm{~A} \times$ Fuk) $\times$ rye & + & + & & + & + & + & $0 / 20$ & 0.00 & \pm 0.15 \\
\hline F1 (Ct mono $5 B \times N 29) \times$ rye & & + & + & + & + & + & $126 / 180$ & 0.70 & \pm 0.07 \\
\hline F1 (Ct mono $5 \mathrm{~B} \times$ Fuk) $\times$ rye & & + & + & + & + & + & $123 / 260$ & 0.47 & \pm 0.06 \\
\hline $\mathrm{F} 1$ (Ct mono $5 \mathrm{D} \times \mathrm{N} 29) \times$ rye & + & + & + & + & & + & $24 / 200$ & 0.12 & \pm 0.05 \\
\hline F1 $($ Ct mono $5 \mathrm{D} \times$ Fuk $) \times$ rye & + & + & + & + & & + & $1 / 100$ & 0.01 & \pm 0.04 \\
\hline
\end{tabular}

+ : presence of the allele. 
Table II. Crossability with rye of the different back-cross progenies, monosomics for chromosomes 5A, 5B, 5D.

\begin{tabular}{|c|c|c|c|c|c|c|c|c|c|}
\hline \multirow{4}{*}{$\begin{array}{l}\mathrm{BC}_{1}(\mathrm{Ct} \text { mono } 5 \mathrm{~A} \times \mathrm{N} 29) \times \text { rye } \\
\mathrm{BC}_{1}(\mathrm{Ct} \text { mono } 5 \mathrm{~A} \times \mathrm{Fuk}) \times \text { rye }\end{array}$} & \multicolumn{6}{|c|}{ Presumed allelic composition } & \multirow{3}{*}{$\begin{array}{c}\text { No of grains/ } \\
\text { No of flowers } \\
\text { pollinated }\end{array}$} & \multirow{2}{*}{\multicolumn{2}{|c|}{$\begin{array}{c}\text { Estimate of the } \\
\text { seed set and } \\
\text { confidence } \\
\text { interval }\end{array}$}} \\
\hline & \multirow{2}{*}{$\frac{K r_{1}}{++}$} & \multirow{2}{*}{$\begin{array}{c}k r_{1} \\
. .\end{array}$} & \multirow[t]{2}{*}{$K r_{2}$} & \multirow{2}{*}{$\begin{array}{r}k r_{2} \\
+\end{array}$} & \multirow{2}{*}{$\begin{array}{c}K r_{3} \\
++\end{array}$} & \multirow{2}{*}{$\frac{k r_{3}}{. \cdot}$} & & & \\
\hline & & & & & & & & 0 & \pm 0.08 \\
\hline & $\cdot+$ & .. & & + & ++ & $\cdot \cdot$ & $0 / 40$ & 0 & \pm 0.08 \\
\hline $\mathrm{BC}_{1}(\mathrm{Ct}$ mono $5 \mathrm{~B} \times \mathrm{N} 29) \times$ rye & & + & + & .. & + & .. & $63 / 180$ & 0.35 & \pm 0.07 \\
\hline $\mathrm{BC}_{1}$ (Ct mono $5 \mathrm{~B} \times$ Fuk $) \times$ rye & & + & + & .. & + & .. & $102 / 240$ & 0.42 & \pm 0.06 \\
\hline $\mathrm{BC}_{1}(\mathrm{Ct}$ mono $5 \mathrm{D} \times \mathrm{N} 29) \times$ rye & $\cdot+$ & .. & + & .. & & + & $1 / 100$ & 0.01 & \pm 0.04 \\
\hline $\mathrm{BC}_{1}$ (Ct mono 5D $\times$ Fuk $) \times$ rye & $\cdot+$ &.$\cdot$ & + & .. & & + & $1 / 80$ & 0.01 & \pm 0.04 \\
\hline $\mathrm{BC}_{2}(\mathrm{Ct}$ mono $5 \mathrm{~A} \times \mathrm{N} 29) \times$ rye & $\cdot+$ & .. & & + & $\cdot+$ & .. & $0 / 80$ & 0 & \pm 0.04 \\
\hline $\mathrm{BC}_{2}(\mathrm{Ct}$ mono $5 \mathrm{~A} \times \mathrm{Fuk}) \times$ rye & ++ &.$\cdot$ & & + & ++ & .. & $7 / 120$ & 0.06 & \pm 0.04 \\
\hline $\mathrm{BC}_{2}(\mathrm{Ct}$ mono $5 \mathrm{~B} \times \mathrm{N} 29) \times$ rye & & + & + & .. & $\cdot+$ & .. & $57 / 140$ & 0.41 & \pm 0.08 \\
\hline $\mathrm{BC}_{2}(\mathrm{Ct}$ mono $5 \mathrm{~B} \times$ Fuk $) \times$ rye & & + & + & .. & ++ & .. & $108 / 200$ & 0.54 & \pm 0.07 \\
\hline $\mathrm{BC}_{3}(\mathrm{Ct}$ mono $5 \mathrm{~A} \times \mathrm{N} 29) \times$ rye & ++ & & & + & ++ & & $1 / 120$ & 0.01 & \pm 0.04 \\
\hline $\mathrm{BC}_{3}(\mathrm{Ct}$ mono $5 \mathrm{~A} \times \mathrm{Fuk}) \times$ rye & ++ & & & + & ++ & & $0 / 40$ & 0 & \pm 0.08 \\
\hline $\mathrm{BC}_{3}(\mathrm{Ct}$ mono $5 \mathrm{~B} \times \mathrm{N} 29) \times$ rye & & + & ++ & & ++ & & $83 / 300$ & 0.28 & \pm 0.05 \\
\hline $\mathrm{BC}_{3}(\mathrm{Ct}$ mono $5 \mathrm{~B} \times \mathrm{Fuk}) \times$ rye & & + & ++ & & ++ & & $119 / 380$ & 0.31 & \pm 0.05 \\
\hline $\mathrm{BC}_{4}(\mathrm{Ct}$ mono $5 \mathrm{~A} \times \mathrm{N} 29) \times$ rye & ++ & & & + & ++ & & $0 / 80$ & 0 & \pm 0.04 \\
\hline $\mathrm{BC}_{4}(\mathrm{Ct}$ mono $5 \mathrm{~A} \times \mathrm{Fuk}) \times$ rye & ++ & & & + & ++ & & $0 / 40$ & 0 & \pm 0.08 \\
\hline $\mathrm{BC}_{4}(\mathrm{Ct}$ mono $5 \mathrm{~B} \times \mathrm{N} 29) \times$ rye & & + & ++ & & ++ & & $53 / 120$ & 0.44 & \pm 0.09 \\
\hline $\mathrm{BC}_{4}(\mathrm{Ct}$ mono $5 \mathrm{~B} \times \mathrm{Fuk}) \times$ rye & & + & ++ & & ++ & & $74 / 120$ & 0.62 & \pm 0.09 \\
\hline
\end{tabular}

$+:$ presence of the allele; $\cdot$ : heterozygous condition and/or uncertain presence.

Fukuhokomugi, ranged from 50 to $60 \%$ (table III). Figure 2 summarizes seed set variations during the development of substitution lines involving chromosome $5 \mathrm{~B}$.

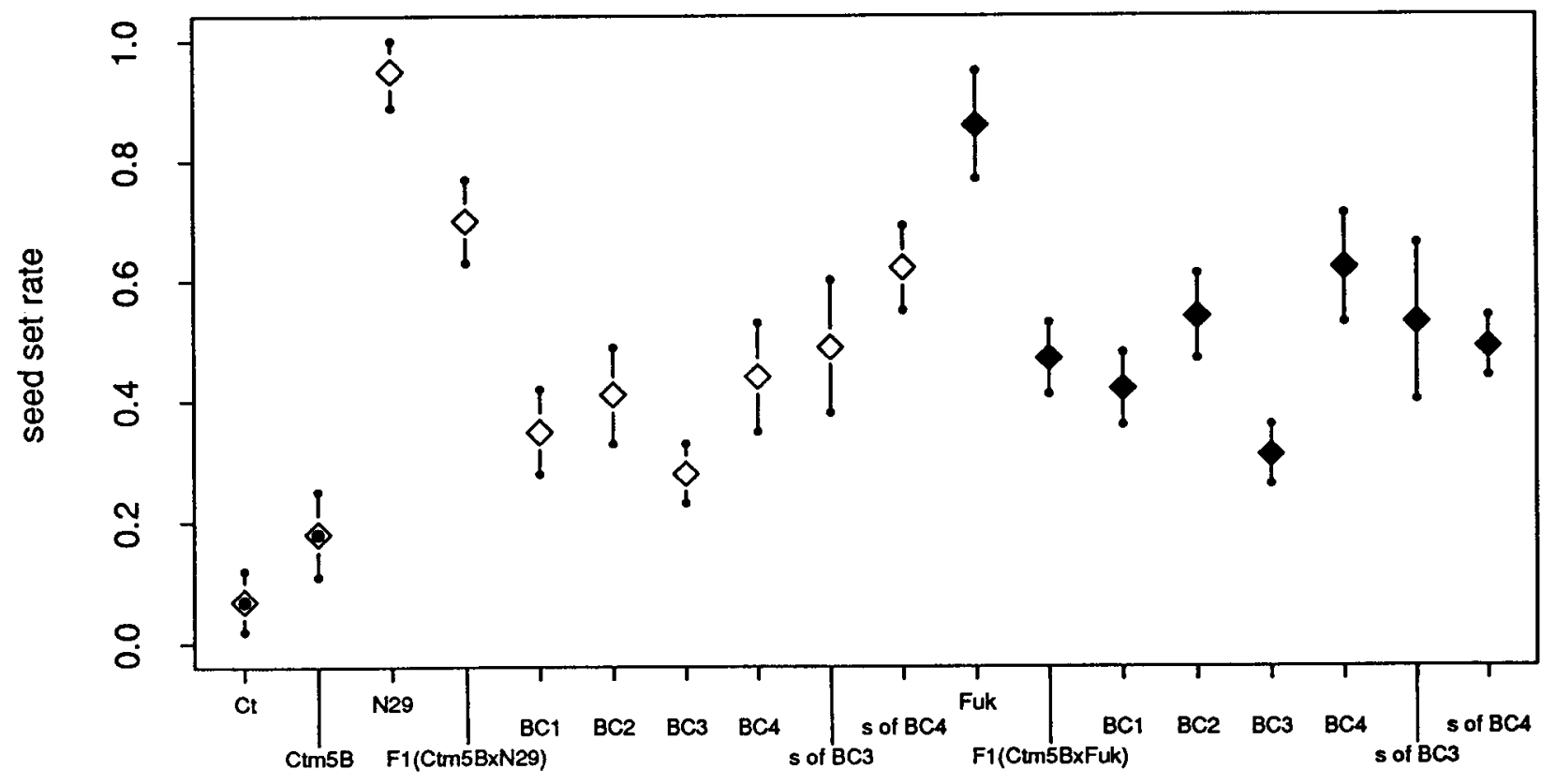

Fig 2. Evolution of seed set during the creation of substitution lines involving chromosome 5B. 
Table III. Crossability of the selfed progenies of $\mathrm{BC}_{3}$, disomic $5 \mathrm{~A}, 5 \mathrm{~B}$ from $\mathrm{N} 29$ and Fuk and the selfed progenies of $\mathrm{BC}_{4}$, disomic $5 \mathrm{~B}$ from $\mathrm{N} 29$ and Fuk.

\begin{tabular}{|c|c|c|c|c|c|c|c|}
\hline \multirow{2}{*}{ Identity of the genotypes } & \multicolumn{5}{|c|}{ Presumed allelic composition } & \multirow{2}{*}{$\begin{array}{c}\text { No of grains/ } \\
\text { No of flowers } \\
\text { pollinated }\end{array}$} & \multirow{2}{*}{$\begin{array}{c}\text { Estimate of the } \\
\text { seed set and } \\
\text { confidence } \\
\text { interval }\end{array}$} \\
\hline & $K r_{1}$ & $k r_{1}$ & $K_{r_{2}}$ & $k r_{2}$ & $K r_{3}$ & & \\
\hline Self of $\mathrm{BC}_{3}(\mathrm{Ct}$ diso $5 \mathrm{~A} \times \mathrm{N} 29) \times$ rye & ++ & & & ++ & ++ & $7 / 100$ & $0.07 \pm 0.05$ \\
\hline Self of $\mathrm{BC}_{3}$ (Ct diso $\left.5 \mathrm{~A} \times \mathrm{Fuk}\right) \times$ rye & ++ & & & ++ & ++ & $1 / 40$ & $0.03 \pm 0.12$ \\
\hline Self of $\mathrm{BC}_{3}(\mathrm{Ct}$ diso $5 \mathrm{~B} \times \mathrm{N} 29) \times$ rye & & ++ & $+t$ & & ++ & $39 / 80$ & $0.49 \pm 0.11$ \\
\hline Self of $\mathrm{BC}_{3}(\mathrm{Ct}$ diso $5 \mathrm{~B} \times \mathrm{Fuk}) \times$ rye & & ++ & ++ & & ++ & $32 / 60$ & $0.53 \pm 0.13$ \\
\hline Self of $\mathrm{BC}_{4}(\mathrm{Ct}$ diso $5 \mathrm{~B} \times \mathrm{N} 29) \times$ rye & & ++ & ++ & & ++ & $112 / 180$ & $0.62 \pm 0.07$ \\
\hline Self of $\mathrm{BC}_{4}(\mathrm{Ct}$ diso $5 \mathrm{~B} \times \mathrm{Fuk}) \times$ rye & & ++ & ++ & & ++ & $208 / 420$ & $0.49 \pm 0.05$ \\
\hline
\end{tabular}

+ : presence of the allele.

\section{DISCUSSION AND CONCLUSIONS}

Although the results showed considerable variation due to environmental factors, they confirmed the strong inhibitory role of allele $\mathrm{Kr}_{1}$ in wheat $x$ rye crossability; a reduction in the dose of $\mathrm{Kr}_{1}$ seemed beneficial by itself. Crossing Courtot monosomic $5 \mathrm{~B}$ (with one $\mathrm{Kr}_{1}$ allele) by rye (table I) gave a seed set of $18 \%$ compared with $7 \%$ with normal Courtot. This suggests an enhancement of the incompatibility effect with 2 doses of $\mathrm{Kr}_{1}$. On the other hand, the effect of a reduction in the dosage of $\mathrm{Kr}_{3}$ was not perceptible, as Courtot monosomic 5D was not different from Courtot. Furthermore, the presence of $\mathrm{Kr}_{1}$ during backcrosses, even at 1 dose, as in F1 (table I), was sufficient to greatly limit seed-setting.

The substitution of $\mathrm{Kr}_{1}$ by $\mathrm{kr}_{1}$ brought an outstanding improvement. The seed set of substituted Courtot $5 \mathrm{~B}$, crossed with rye was close to $50 \%$. In contrast, substitution of $\mathrm{Kr}_{2}$ and $\mathrm{Kr}_{3}$ by their recessive alleles $\mathrm{kr}_{2}$ and $\mathrm{Kr}_{3}$ had no effect, at least in the presence of $\mathrm{Kr}_{1}$. This result tends to confirm the active antagonistic effect of the dominant allele $\mathrm{Kr}_{1}$. It would be interesting to refine this study by comparing the $5 \mathrm{~B}$ nullisomic and $5 \mathrm{~B}_{\mathrm{S}}$ ditelosomic of Courtot with the $5 \mathrm{~B}$ substitution lines and to evaluate the crossability of genotypes associating 2 and 3 crossability genes. Moreover, we plan to continue the back-cross process to obtain substitution lines as close to Courtot as possible, with less than $6 \%$ of genetic differences as expected in $\mathrm{BC}_{4}$; the monosomic $\mathrm{BC}_{5}$ generation is already available.

The comparison of the seed set in the crosses between Japanese wheat varieties or the substitution lines and rye showed a relatively strong inhibitory effect of $\mathrm{Kr}_{2}$ and $\mathrm{Kr}_{3}$ (fig 2). Analysing a diallel cross involving all possible substituted genotypes should make it possible to determine the genetic relationships between the different genes involved. While it is clear that partial dominance exists at each locus, the relationships between loci have not been entirely elucidated.

The cytological study of the 9 mono Courtot $5 \mathrm{~B} \times$ rye $\mathrm{F} 1$ plantlets showed a distribution close to the normal disjunction in the female gametogenesis of a 5B monosomic plant of Chinese Spring (70\% of 20-chromosome gametes, $30 \%$ of 21-chromosome gametes). This observation means that the action of inhibitory alleles is sporophytic rather than gametophytic, since ovules with 20 and 21 chromosomes are fertilized as expected. This is in accordance with the conclusions of Lange and Wojciechowska (1976), who showed that the $\mathrm{Kr}_{1}$ and $\mathrm{Kr}_{2}$ alleles act as inhibitors of pollen tube growth at the micropyle.

From a practical point of view, using substitution lines of chromosomes $5 \mathrm{~B}$ from Norin 29 and Fukuhokomugi into Courtot has major advantages. A seed set of $50 \%$ makes it easier to create primary octoploid triticale and therefore to enlarge the genetic variability of this species. The availability of a crossable wheat genotype with a satisfactory agronomic performance would enable an effective screening of rye populations for their aptitude to give triticale material with interesting biological and agronomical characteristics. In particular, since the Courtot genotype possesses the Rht ${ }_{1}$ and $\mathrm{Rht}_{2}$ dwarfing alleles, and is of good baking quality, we may obtain short triticales with satisfactory technological properties. The availability of a generalized 
labelling system of the Triticeae genome (RFLP, or other), should make it possible to identify in the rye genome the chromosome segments bearing genes which favour the expression of the above-mentioned characters, either directly or by favorable interaction with their homoeoalleles present in wheat.

\section{REFERENCES}

Backhouse WO (1916) Note on the inheritance of "crossability". J Genet 6, 91-94

Cauderon Y, Gay G (1992) In: Techniques de cytogénétique végétale (J Jahier ed) INRA, 10 and 44

Denis JB, Bernard M, Arnoux J, Cauderon Y (1982) Analyses statistiques des configurations méiotiques lors de la création d'une série monosomique du blé tendre "Courtot". agronomie 2, (8) $701-708$

Falk DE, Kasha KJ (1981) Comparison of the crossability of rye (Secale cereale) and Hordeum bulbosum onto wheat (Triticum aestivum). Can J Genet Cytol 23, 81-88

Fedak G, Jui PY (1982) Chromosomes of Chinese spring wheat carrying genes for crossability with Betzes barley. Can J Genet Cytol 24, 227-233

Florell VA (1931) A genetic study of wheat-rye hybrids and backcrosses. J Agric Res 42, 315-340

Inagaki M, Tahir M (1990) Comparison of haploid production frequencies in wheat varieties crossed with Hordeum bulbosum $L$ and Maize. $J J$ Breed 40, 209-216

Kaltsikes PJ (1974) Methods for triticale production. Z Pflanzenzücht 71, 264-286

Krolow KD (1970) Untersuchungen über die Kreuzbarkeit zwischen Weizen und Roggen. Z Pflanzenzücht $64,44-72$

Lange W, Wojciechowska B (1976) The crossing of common wheat (Triticum aestivum $L$ ) with cultivated rye (Secale cereale L). I. Crossability, pollen grain germination and pollen tube growth. Euphytica 25, 609-620

Laurie DA, Bennett MD (1987) The effect of the crossability loci $\mathrm{Kr}_{1}$ and $\mathrm{Kr}_{2}$ on fertilization frequency in hexaploid wheat $x$ maize crosses. Theor Appl Genet 73, 403-409

Laurie DA, Bennett MD (1988) The production of haploid wheat plants from wheat $\times$ maize crosses. Theor Appl Genet 76, 100-105

Lein A (1943) Die genetische Grundlage der Kreuzbarkeit zwischen Weizen und Roggen. Indukt Abstamm und Vererb lehre 81, 28-61
Marais GF, Pienaar R de V (1977) Hybridisation between wheat and rye. II. Variations in the germinability of the hybrid kernels with special reference to the effect of the D-genome. Agroplantae 9, 143-148

Marais GF, Van Der Westhuizen 'MSS (1987) Hybrid seed development and viability in crosses of $T$ aestivum (cV Chinese spring) monosomic lines with $S$ cereale. Theor Appl Genet 74, 503507

Marais GF (1988) Effects of wheat chromosome $1 D$ telosomes on hybrid seed development in wheat $\times$ rye crosses. J Plant Breed 100, 157159

Pienaar R de V, Marais GF (1976) The effect of $D$-genome on kernel set and viability in wheat $x$ rye crosses. Wheat Inf Serv 43, 4-9

Pienaar R de V, Marais GF (1986) Effect of Dgenome chromosome substitutions on hybrid seed development and viability in $T$ turgidum var durum $\times S$ cereale crosses. J Plant Breed 97, 112-118

Rimpau W (1891) Kreuzungsprodukte landwirtschaftlicher Kulturpflanzen. Landwirtsch Jahrbuch Schweiz 20, 355-371

Riley R, Chapman $V$ (1967) The inheritance in wheat of crossability with rye. Genet Res Camb 9, 259-267

Scoles GJ (1983) The effect of rye genotype on wheat-rye crossability and on the development of F1 seed. Can J Genet Cytol 25, 668-670

Sitch LA, Snape JW, Firman SJ (1985) Intrachromosomal mapping of crossability genes in wheat (Triticum aestivum). Theor Appl Genet 70, 309-314

Stefanowska G, Cauderon $Y$ (1983) L'aptitude au croisement avec le seigle (Secale cereale L) d'une lignée hexaploïde de Triticum (cv Roazon) résultant d'hybridation interspécifique (Gramineae Juss). agronomie 3, 355-358

Taira T, Lelley T, Larter EN (1978) Influence of parental rye on the development of embryos and endosperm of wheat-rye hybrids. Can J Bot 56, 386-390

Tanner DG, Falk DE (1981) The interaction of genetically controlled crossability in wheat and rye. Can J Genet Cytol 23, 27-32

Tozu T (1950) On the crossability between wheat (Triticum vulgare) and rye (Secale cereale). Jpn $J$ Genet 25, 90-95

Unrau J, Person C and Kuspira J (1956) Chromosome substitution in hexaploid wheat. Can J Bot 34, 629-640

Zeven AC (1987) Crossability percentages of some 1400 bread wheat varieties and lines with rye. Euphytica 36, 299-319 